\title{
Regional resilience and spatial cycles: long-term evolution of the Chinese port system
}

\section{(221 BC - $2010 \mathrm{AD})$}

\author{
Chengjin WANG \\ Key Laboratory of Regional Sustainable Development Modeling \\ Institute of Geographical Sciences and Natural Resources Research (IGSNRR) \\ Chinese Academy of Sciences (CAS) \\ Beijing 100101, China \\ cjwang@igsnrr.ac.cn
}

César DUCRUET ${ }^{1}$

French National Centre for Scientific Research (CNRS)

UMR 8504 Géographie-cités

F-75006 Paris, France

cdu@parisgeo.cnrs.fr

Pre-final version of the paper published in Tijdschrift voor Economische en Sociale Geografie, Vol. 104, No. 5, pp. 521-538.

\begin{abstract}
Spatial models of port system evolution often depict linearly the emergence of hierarchy through successive concentration phases of originally scattered ports. The Chinese case provides a fertile ground for complementing existing works by a long-term perspective, given the early importance of river ports and seaports and the development irregularities caused by periods of closure and openness over time and across such a large land mass. In both qualitative and quantitative ways, this paper describes and analyzes the changing spatial pattern of China's port system since the first unified empire (221 BC). Main results underline a certain stability of the port system with regard to the location of main sea-river gateways, notwithstanding important regional shifts from one period to the other.
\end{abstract}

Keywords: China; port system; spatial evolution; transport system

\section{Introduction}

As one of the world's most ancient civilizations and despite several reconfigurations of its national territory, China has always kept a subtle relationship between land and water, mainland culture and maritime culture,

${ }^{1}$ Corresponding author 
throughout its history (FAIRBANK, 1983). Early aware of the advantage of water transportation, China developed route-schedule-oriented shipping with Japan and Korea, and dug the world's first canal in the Spring and Autumn Period before 256 B.C, while owning the most advanced shipbuilding technology in the Han Dynasty during 256 B.C-220. The Tang and Song Dynasties (618-1279) saw the establishment of the Maritime Silk Road linking China with Europe and the Middle-East. For instance, the development of the shipping compass during the Song Dynasty and its adoption by Europe in the late $12^{\text {th }}$ century played a decisive role in the expansion of Europe's influence through sea voyages and the discovery of the New World (NEEDHAM, 1954). Other examples of China's prominence in shipping activities are the digging of the world's longest canal (Grand Canal) during Yuan Dynasty, and the regular sailings of admiral Zheng He (1405-1431) expanding China's trade networks up to East African coasts during Ming Dynasty (1368-1644). Ports and the shipping industry have thus always played a strategic role in the socio-economic development of China, should they be in the hands of merchants or under the control of the central government (GIPOULOUX, 2009). Despite the early and continued importance of river shipping under various periods in China (WEI, 1987), its role has not been as central as in England in the industrialization process during the nineteenth century (TVEDT, 2010), a process which was hampered by a lower innovation capability than in the West, despite the advantage of demographic size (LIN, 1995). One limiting factor in the spread of transport connectivity in China has always been the size of the territory as well as the distance between main economic regions (COMTOIS, 1990). Only ports could have remedy such constraints through both inland and coastal shipping.

The long-term approach to the evolution of the Chinese port system has two main motivations. First, it wishes to confront the Chinese case with the regularities proposed by port system evolution models developed in geography. The concept of port system is generally defined based on geographic proximity between ports on various levels, or simply as a set of ports located within common national boundaries. Port system evolution models describe both concentration and de-concentration factors across successive development phases, notwithstanding important differences between developed and developing countries. Notably, it is interesting to verify to what extent Chinese ports share with other Asian ports a certain level of resilience, which is the ability of absorbing external changes (FOLKE, 2006). In the case of ports and transport systems, resilience is a useful concept that has been rarely used despite its relevance for discussing the extent to which the spatial pattern of flows has remained stable over time, notably during drastic changes in trading route location, operational practices, and technological standards (RODRIGUE et al., 1997). Second, the Chinese case itself has not been fully documented with regard to the long-term existence of port activities in China and to the various political and economical contexts they have been through. While the Chinese literature remains rather dispersed (see Appendix 1), the Western literature about Chinese ports has mostly focused on the last few decades by discussing the spatial effects of containerization (FRANKEL, 1998; COMTOIS and DONG, 2007; RIMMER and COMTOIS, 2009). Case studies of local port development provided more detailed evidence about the diffusion of technological innovation and its actors (AIRRIESS, 2001; CULLINANE et al., 2004, 2005; WANG and SLACK, 2000, 2004; WANG et al., 2004; WANG and DUCRUET, 2012). More comprehensive works in terms of time coverage do not discuss the port system itself as a distinct entity (DENG, 1997).

The remainder of the paper is as follows. Section 2 reviews fundamental models of port system evolution in geography and introduces the methodology for a long-term analysis of the Chinese port system. Section 3 is a qualitative analysis of port development in China before 1840. Section 4 is a quantitative analysis over the rest of the period following 1840. Section 5 discusses the outcomes of the analysis and its implications for further research in the field of port and regional development. 


\section{Conceptual background and methodology}

\subsection{Port system evolutionary models}

The literature on the evolution of port systems provides a number of models and case studies describing phases and transitions in the changing distribution of port traffics. Most models are in fact adjustments of the original one by TAAFFE et al. (1963) elaborated from the case of Ghana and Nigeria across the 1900-1958 period and discussing the emergence of large port gateways concentrating both landward corridors and seaward flows within a given set of adjacent ports. While the generic character of this model has been extensively discussed elsewhere (WEBER, 2004), several authors have refined certain aspects of the original version such as its dominant land-based dimension (BUTLAND, 1966; STANLEY, 1970), the lack of elements about maritime dynamics (RIMMER, 1967a; 1967b), the possibility for non-linear evolutions such as successive inland and coastal concentrations (OGUNDANA, 1972) as well as local specificities causing deviations from universal trends (see HILLING, 1977; AIRRIESS, 1989; HOYLE and CHARLIER, 1995).

Several recurrent concentration and de-concentration factors have been identified in a recent synthesis (DUCRUET et al., 2009a) that can be confronted to the Chinese case. Concentration often occurred through successive phases due to reinforcement of the dominant position of the largest port city for instance (KENYON, 1970; HOYLE, 1999; BRUNT, 2000) through an accumulation process of new infrastructures and traffics at the head of already established sea-land corridors (see also SLACK, 1990; KUBY and REID, 1992). De-concentration is likely to stem from diverse phenomena such as lack of space and diseconomies of scale in large load centers causing the emergence of new ports and/or the reactivation of secondary ports to cope with traffic growth (HAYUTH, 1988), carrier decisions to select smaller ports for intermodal services (SLACK, 1985), and technological change such as the spread of containerization giving privilege to certain locations such as offshore hubs and inland/dry ports for efficient cargo distribution in a context of hinterland expansion and maritime network reconfiguration especially in liner shipping (NOTTEBOOM and RODRIGUE, 2005). Certain ports and port systems have been more or less resilient to such changes depending on their ability to absorb innovations and new logistics practices without fundamentally modifying the pattern of flows and port hierarchies. Notably, major Asian ports exhibit a stronger resilience to external changes, due to the stability of hinterland configurations based on a high concentration of economic activities at coastal areas, compared with Western Europe and North America where port competition has been fiercer for serving continental markets (LEE et al., 2008). Such processes echo wider concentration and dispersion dynamics interpreted by the New Economic Geography (NEG) in terms of core-periphery patterns and transport costs. In the case of transport nodes and ports, the NEG describes the emergence of intermediate locations (e.g. hubs) after a period of growth at established settlements. Such hubs may themselves become cities and core regions during a third phase or remain in the 'shadow' of the established centers (FUJITA and MORI, 1996). The specificity of the NEG approach is thus to consider urban and regional elements while port system models only refer to transport and logistics, but their phased development remains highly comparable.

Confronting the Chinese case to such models and factors over a long time period thus has two main ambitions. First, it wishes to clarify the applicability of existing evolutionary models to a port system having been through successive periods of maritime trade openness and closure while spreading over a very large territory. Second, it aims at evaluating the relationship between social-economic changes and port system evolution, such as shifts in national capital location, domestic, and international trade patterns. 


\subsection{Methodology for a long-term analysis of the Chinese port system}

The availability of historical records of port development dating back to 2,500 B.C. allows to analyze the changing hierarchy of Chinese ports over time (see Appendix 1), notwithstanding many difficulties. Due to mismatched national boundaries from one period to the other, we chose to analyze the entire port system based on the current territory of the People's Republic of China (PRC). The study period ranges from the first unified empire (221 B.C.) to about 2009 and is divided according to six main periods marked by both natural experiments (DIAMOND and ROBINSON, 2010) and changes in political regimes: the Grand Canal completion (604), the first maritime bans (1292), the Opium Wars (1840), the planned economy (1949), and the market economy (until nowadays). Hong Kong, Taiwan, and Macau ports are mentioned whenever relevant but are not considered to be Chinese ports in this study.

Documenting in a balanced fashion such periods was the biggest difficulty of this research. Indeed, it is only after the British-Sino War that customs officers started publishing harmonized and complete port traffic statistics, while since the 1950s, systematic traffic data are published yearly. The lack of statistical data before 1840 forced us to estimate the level of port activities based on local chronicles and historical studies. Based on Appendix 1, the level of port activities at key locations was estimated qualitatively according to several criteria: status and function of ports, amount of vessel calls and grain shipping, gateway role for the Maritime Silk road (e.g. Han Dynasty), position on main shipping routes, shipping mileage, presence and size of warehousing, shipbuilding, ship management, and customs activities. To complement such estimations, we collected population figures for port cities as a proxy for economic and hinterland importance. In contrast with port activities, demographic size is often provided by original sources in numbers of inhabitants even for early time periods. Population figures were obtained from Chinese sources for ancient periods as indicated in Appendix 1. Demographic size is used in this research for testing the link between port activities and local development. Port traffic data were obtained for the 1868-1928 period from Statistics of China's Foreign Trade and for the 1932-2009 period from the Yearbook of China Transportation and Communication. Monetary values prior 1928 in Hong Kong Taels ${ }^{1}$ were converted into tonnage for allowing comparison with subsequent years. Yet, the 1868-1928 customs data comprises only international trade while for the 1932-2009 period both domestic and international traffics are mixed without any possibility distinguishing them. Many ports remain absent from the 1950-1978 period due to their administration by local authorities and limited traffics.

While the cartography of port hierarchies covers the whole period, quantitative methods could only be applied between 1868 and 2009. The number of ports, the traffic share (\%) of the largest port(s), and the concentration level of port traffics are classic indicators used in port system studies (Notteboom, 2006). Their evolution indicates whether traffic distribution reflects or contradicts wider political and territorial changes. The Gini index is a measure of statistical dispersion describing the inequality among values of a frequency distribution, ranging from 0 (perfect equality) to 1 (maximal inequality). The Herfindahl-Hirschman Index (HHI) is a complementary measure based on the size and market share of ports, which underlines decreasing competition and increased market power when its value gets close to 1 over time. Another approach to port hierarchy in this paper is the application of Zipf's law to port traffics. The Pareto-Zipf or rank-size distribution is a useful way to revealing the evolution of hierarchical structures over time, which has been extensively used in urban studies (Bretagnolle et al., 2009). It helps understanding how initial differences tend to persist over very long periods. Adjustment slopes of the power-law lines at each year are retained to summarize successive configurations of the port system. 


\section{Evolution of the Chinese port system before 1840}

\subsection{River ports, canal ports, and waterways}

Early port development mostly occurred inland along rivers and canals through continuous digging and dredging efforts (SHENG, 1931). The waterway network developed in the central plain (including Henan and parts of Shandong and Anhui) and the Yangtze River Delta during the Spring-Autumn and Warring States period (770-221 B.C.) was extended during Qin and Han dynasties to improve continental connectedness $^{2}$, support military efforts, and land conquests. Important river ports emerged in the vicinity of large cities, such as Luoyang and Dingtao near the capital city Xi'an (Figure 1) serving as transshipment centers for grain and other various commodities. Rapid urbanization in Xi'an and nautical limitations of the Sanmen canyon were counterbalanced by the rise of additional ports at river junctions (e.g. Kaifeng, Jingzhou, Shangqin) and river terminals (e.g. Hangzhou, Suzhou). Port development in the early phase is thus much dedicated to the core political region concentrating population, army, and offices to be supplied grain from other production regions such as the Yangtze and Huai river valleys. Southward population shifts caused by continuous wars in the North accentuated this spatial mismatch by fostering the development of the Yangtze River Delta into the main economic region.

\section{[Insert Figure 1 about here]}

During Sui and South Song dynasties (581-1279), several canals are created to complement the aforementioned system ${ }^{3}$ while Yangzhou, Luoyang, and Kaifeng become the main hubs of the river-canal shipping network between Hangzhou and Xi'an. As the capital city of Sui and Tang dynasties (581-907), Xi'an maintains important shipping activities for grain transport with records of 200-300 vessels daily (Old Tang Book) despite limitations imposed by the Sanmen canyon (ZHU, 1962). In parallel, growing East-West traffic along the Yangtze river fosters the emergence of Chengdu, Chongqing (upper reach), and Wuhan (middle reach) that connect Yangzhou, Suzhou, and Hangzhou (JIN, 1986). The shift of the national capital northward to Beijing during Yuan and Ming dynasties motivates the strengthening of North China's river-canal system through the creation of the Grand Canal linking many ports (see Figure 1). The role and importance of individual ports changes over time but without altering the reinforcement of this North-South axis ${ }^{4}$. Such dynamics further accentuate the bipolar spatial structure between North and South while enticing the economic growth of southern regions such as Fujian and the Pearl River Delta, which persists nowadays.

Before the British-Sino war, river and canal shipping continue to develop rapidly while reaching a peak of activity. The Grand Canal, the Yangtze River, but also coastal domestic routes become increasingly interconnected, thus forming a single system on the level of the entire river-canal shipping network. Traffic concentrates along the Yangtze River and the coastal corridors that link a continuous alignment of canal and river ports, whereas Huai'an and Huaiyin have a key role for canal shipping between the Grand Canal and the Huai River. The empirical analysis by SHIUE (2002) of eighteenth century China demonstrated the high level of interregional trade integration despite high transport costs, notably due to well established waterway networks. Under Ming and Qing dynasties (1616-1911), the central government establishes the Viceroy Ministry Shipping Canal as well as transshipping warehouses at both sites, Huaiyin benefiting from the dredging of Qingjingpu River. With regard to its central location upon the Grand Canal, another branch of the Ministry was established by Ming and Qing governments in Jining as well as a transshipping warehouse, resulting in the daily berthing of thousands of ships. Other intermediate river hubs for North-South grain distribution develop at that period, such as Linqing (Huitong Canal) and Dezhou, mainly to remedy the 
spatial mismatch between core political region and core economic region. The opening of the Beijing-Tianjin railway (1898) ultimately provoked the rapid decline of Tongzhou and Zhangjiawan, where Beijing's grain terminal was previously shifted. In other regions, river shipping continues to play a vital role, notably articulated among Yangtze River gateways such as Wuhan (Hubei-Hunan plains and east-west hub), Chongqing (Sichuan basin), Wuhu and Jiujiang (rice and local products exports) as well as Hangzhou, Suzhou, and Wuxi (distribution centers).

\subsection{Seaports and maritime trade}

As early as the Spring-Autumn period, coastal domestic routes are opened between Shandong peninsula and Yangtze River Delta. The first international shipping routes opened under Qin and Han dynasties linking Shandong with Japan, Korea, Vietnam, and Rome (FANG, 2003), but silk exports and jewelry imports to/from the West still occur mostly by land transport through Central Asia and the Silk Road. The coastal area remains largely underdeveloped with the exception of the Pearl River and notably Guangzhou, an important gateway since Shang dynasty (1600-110 B.C.) and China's largest port during the Warring States period, due to its connections with the maritime silk road, and the Yangtze River Valley through Dayuling road (Qin Dynasty). Nevertheless, comparable port development occurs across the Yellow Sea through the Jinzhou/Korea-Japan and Fuzhou/Vietnam links. From the late thirteenth to the nineteenth century, China's maritime trade remains highly regulated by the central government through a tributary system (GIPOULOUX, 2009). This control has been more or less tight over time depending on the level of emphasis put on inland matters, such as Mongol invasions and a preference for agricultural and intellectual activities promoted by Confucianism. In fact, banning maritime trade often resulted in fostering contraband activities and piracy involving Chinese merchants themselves (see Figure 2). Brokerage, entrepôt, and transit trade activities shifted from Chinese ports to other locations such as the Ryukyu archipelago in Japan (1372-1550) and the Zheng Dynasty in Taiwan (1624-1683) during bans, thereby reinforcing Chinese presence throughout East and South Asia.

\section{[Insert Figure 2 about here]}

Under Sui and South Song dynasties (581-1279), maritime trade is strengthened within East Asia but also towards India, the Arabian Peninsula, and Africa based on intense and rapidly growing port activities (ZHANG, 1986) and at the expense of inland transport. Exported cargoes included silk, tea, and porcelain, while main imports were jewelry, spices, and leechdom, notably through the Srivijaya and Malacca kingdoms that played an intermediary function between China and India from the $3^{\text {rd }}$ to the $14^{\text {th }}$ centuries (GIPOULOUX, 2009) with the support of Chinese merchants. About two-thirds of China's international trade was using maritime transport at the eve of Song Dynasty, when the Maritime Silk Road was reactivated partly due to the blockade of land-based routes (GIPOULOUX, 2009). Natural disasters and migrations from the North largely contributed to important population shifts towards southeastern areas and to the growth of Guangzhou, which remains the largest seaport and main hub with regard to the diversity and weight of its maritime forelands $s^{5}$ as well as the major shipbuilding centre together with Fujian province. Although continuous wars and rebellions (e.g. An-Shi) have not put in question Guangzhou's supremacy, other ports emerged such as Quanzhou and Fuzhou ${ }^{6}$ in the South, Penglai navy base and Zhucheng in the North (ZHANG, 1986). Yangzhou became China's second largest port and main gateway to the Yangtze River ensuring grain distribution for Xi'an (Tang dynasty). War destructions and geophysical evolutions motivated important traffic shifts to Yizheng, Ningbo, and Shanghai during late Tang and South Song dynasties, which witnessed rapid increase in maritime trade with the Indian Ocean for the import of more than 410 kinds of products and the export of porcelain and silk. 
Under Yuan Dynasty, Chinese seaborne shipping reaches a peak of prosperity. The shift of the capital city from Kaifeng to Hangzhou in South Song Dynasty fostered maritime activities under Ming dynasty (GIPOULOUX, 2009). International shipping routes towards Europe, Africa, and the Middle East were developed through the maritime explorations of Admiral Zheng $\mathrm{He}$ and strengthened trading networks across Southeast Asia. China as a whole had about 145 trade partners under Yuan Dynasty, while its exports under Ming Dynasty were as diverse as 236 kinds of goods (FANG, 2003). The southeastern ports of Quanzhou ${ }^{7}$, Guangzhou, and Ningbo became the largest seaports during Yuan Dynasty, while Xiamen (Zhangzhou) developed as intermediary location between Fuzhou and Guangzhou. Benefitting from Hangzhou's physical limitations, Ningbo reached the third rank during maritime openness in Ming Dynasty. In the Bohai Rim, Tianjin becomes Beijing's gateway and an important river port connecting the Grand Canal. Trade decline under Yuan Dynasty, tensions with Mongols, and Japanese piracy (Ryukyu and Wako) caused the gradual decline of several ports in the North (e.g. Zhucheng) and in the South due to their remoteness from Beijing (e.g. Fuzhou, Macau, Huizhou, and Taizhou). The dredging of Huangpu River fosters the development of Shanghai port shifting China's trade center from Guangzhou to Shanghai (ZHANG, 1986). The ban of maritime trade during Ming government is compensated by a continued improvement of the canal network, which supports a yearly grain traffic of about 10,000,000 $s h i^{8}$ under Ming Dynasty. Since the ban of the maritime trade, the Grand Canal becomes the trunk corridor of grain transport and fosters the canal-port belt. As seen in Figure 1, the importance of seaports has shrunk compared with river ports notably due to such bans, although the pattern of seaport activities still underline the importance of three main regions.

In addition, rising European colonial interests (e.g. Portuguese, Dutch) and Japanese piracy motivated the ban of foreign maritime trade until 1684 except at Guangzhou, which became directly connected to Holland in 1756 by European vessels instead of Chinese junks. Illicit activities thus rapidly developed through Diaspora networks in Southeast Asia until port operations restarted at Xiamen, Quanzhou, and Shanghai (GIPOULOUX, 2009) notably for coastal trade with northern seaports such as Tianjin and Yingkou, the latter having benefitted traffic shift from Niuzhuang in the late $17^{\text {th }}$ century due to technological change and increase in grain transport between Liaoning and Beijing (ZHANG, 1986). Already established ports have been thus been easier to overcome disruption, such as Xiamen becoming Fujian's main gateway and Tianjin as Beijing's gateway. The maritime ban of 1757 (Figure 2) closing Shanghai, Ningbo, and Quanzhou only let Guangzhou port to trade and control silk and tea. This action marks the beginning of an isolation policy that maintained until the Opium Wars.

\section{Evolution of the Chinese port system after 1840}

\subsection{From the Opium Wars to 1949}

The intervention of foreign countries is believed to have provoked a rupture in the development of China's port system (MURPHEY, 1974). Seaports have gradually become dominant at the expense of river ports (Figure 3), due also to the siltation of the Grand Canal and the development of north-south rail transport and coastal shipping since the early twentieth century (FU, 2005). The treaty ports system launched in 1842 favored selected seaports serving colonial interests. Chinese treaty ports exchanged more with each other and with Korean and Japanese treaty ports than with their hinterlands, with Shanghai being the main distribution hub of European products (e.g. wool) and Hong Kong the main financial center within an Asian trading network mostly controlled by Chinese merchants (GIPOULOUX, 2009). Traffic polarization upon few main seaports favored Shanghai, Guangzhou, and Dalian although many other ports were opened to 
foreign trade after the loss of independence ${ }^{9}$. Mainland China remained a rather autarchic system as foreign trade did not penetrate much the interior: treaty ports remained enclaves containing further expansion of European powers.

The Yangtze River becomes the trunk line of China's river shipping network, with Shanghai port rising rapidly as the main gateway between the river corridor and maritime routes towards Xiamen, Hong Kong, and Dalian. Shanghai has reached and maintained its position as the country's major port along the period, thus replacing Guangzhou at the top of the hierarchy. Junk trade clearly concentrated along the Yangtze River around 1930 with Shanghai handling the largest share (WIEN, 1955). Such development greatly modifies the primary spatial pattern of the port system that was established since Qin Dynasty. Hong Kong, established in 1843 by the British Empire as a gateway to China's conquest, progressively and durably takes over Guangzhou's role as main hub for South China. Fuzhou also develops rapidly and achieves $11.5 \%$ of China's total port traffic in 1868. Initially planned by Russia (1898) as the gateway to the Far East and mainly used by Russia and Japan for exploiting Northeast China's resources, Dalian accounted for about $15 \%$ of Northeast China's maritime traffic in 1907 and reached a traffic of about 10 million tons in 1934, becoming second largest port after Shanghai. Dalian thus surpassed Tianjin, which encountered siltation problems as well as military disturbances in the early 1930s (HITCH, 1935). In 1902, Tianjin's modal share of inland traffic remains mostly river-based (69\%, of which $19 \%$ on the Grand Canal) compared with railways (24\%) and roads (7\%) due to the maintained importance of "junk" vessels (WIEN, 1955). Northeastern ports rapidly emerged as a distinct subgroup, alongside the central region polarized by Shanghai and the southeastern region centered upon Guangzhou and Hong Kong.

[Insert Figure 3 about here]

Growing discrepancies between river/canal ports and seaports as well as among seaports also found its roots in the introduction and popularization of modern transport modes connecting established coastal poles. Such dynamics reflect upon the aforementioned port system evolution models as discussed earlier. The introduction of railways along the Grand Canal accelerated the decline of river/canal shipping. The Beijing-Wuhan (1906) and Beijing-Nanjing (1911) lines are good examples of inland expansion by concentric rings while capturing traffic from the Grand Canal (WANG et al., 2009). Similarly, railway bridges with low height constrained the passage of large vessels on the Yangtze River. Other important railway lines connecting seaports were Jinan-Qingdao, Haerbin-Dalian, and Wuhan-Guangzhou. For instance, the Haerbin-Dalian line (1905) quickly fostered the activity of the newly opened Dalian port (1908) while forming Northeast China's main corridor and expanding the port's hinterland and traffic. Yet, Shanghai's prominence in the port system remained much explained by intense river traffic along the Yangtze and its role as a hub for inland river ports such as Wuhan (TANG, 2009).

\subsection{From 1949 to 2009}

After 1949, China implements the planned economy and focuses on the development on inland areas, as seen with the expansion of the railway transport system westward (WANG et al., 2009). Especially during the 1949-1965 period, limited international trade tends to hamper seaports, but river shipping remains busy as the development of river ports, notably along the Yangtze, is of chief concern for the national transport policy (see also Figure 3). Shanghai maintains its key role as a river hub port, accounting for $33.8 \%$ of total traffic in 1959, but Hong Kong becomes China's main maritime hub. Chongqing, Wuhan, and Nanjing are important river hub ports polarizing Yangtze River's upper, middle and lower reaches respectively, while Dalian and Qingdao keep their maritime role despite important traffic gaps with regard to Shanghai's activity. 
Heavy investments in transport infrastructure during the 1966-1973 period towards western regions aimed at mitigating the disparities between the coastal region and inland region.

In the late 1970s, the Open Door Policy shifted the focus of development to the coastal areas, thereby putting in question balanced regional development policies as in the Pearl River Delta (LO, 1989). Fourteen coastal cities and five Special and Coastal Economic Zones are selected in 1984 to develop international trade based on export-oriented industries and seaports, such as Shenzhen, Shanghai, Qingdao, Tianjin, Xiamen, and Dalian. In this phase, the number of ports dramatically increases, while each sub-region becomes polarized by one or few large ports. Shanghai maintains its centenary role as East China's main hub and gateway of the Yangtze River Delta, reaching a traffic of 590 million tons in 2009. In the Bohai Rim, Dalian, Tianjin and Qingdao are the main ports of Liaodong Peninsula, West Coast, and Shandong Peninsula with a respective traffic of 200,380, and 315 million tons in 2009, despite some limitations felt at Tianjin, for instance, in terms of maritime and landward accessibility (TODD, 1994).

In the South, Guangzhou reaches a traffic of 375 million tons making it the largest port of the Pearl River Delta, thereby gradually resuming its historic role. A recent comparative study of Chinese ports clearly illustrated the permanency of Guangzhou's foreland diversity among other trends (WANG and NG, 2011). In comparison, the importance of Hong Kong as a port weakens continuously, attaining a traffic of 243 million tons in 2009, as a result of important traffic shifts towards mainland ports and a preference for more valued activities than sole transshipment (WANG and CHEN, 2010). The rapid development of river shipping, notably for containers, fosters the traffic of several inland river ports along the main axis of the Yangtze River (VEENSTRA and NOTTEBOOM, 2011). Ports of the lower reaches expand quicker and have larger traffic sizes (e.g. Nanjing and Zhenjiang), Wuhan becomes the main port of the middle reaches, and ports of the upper reaches the ports develop relatively slowly. Several smaller river ports emerge in different areas, such as Guigang and Wuzhou (Pearl River), Haerbin and Jiamusi (Songhua River), and Xuzhou and Jining (Grand Canal). The rapid rise of other main seaports such as Ningbo (384 million tons), Shenzhen (194 million tons) for containers and Qinhuangdao (244 million tons) for energy exports (e.g. coal) is another important trend influencing the Chinese port system profoundly.

\subsection{Concentration dynamics during the 1868-2009 period}

Port traffic evolution clearly indicates a major rupture in the late 1940s and early 1950s (Figure 4) caused by the transition to a socialist regime. Such political shift signified the end of foreign intervention. Traffic volumes, however, rapidly recovered in the early 1960s and went back to pre-1928 levels in the mid-1980s. Indeed, many ports were gradually reopened for domestic activities and limited foreign traffics after 1949. Contrastingly, the level of concentration (Gini coefficient) has remained lower after 1949, following a regular increase and peak until 1928. Concentrations restarts after 1949 but within much lower levels. This might be partly explained by the fact that international traffic (1868-1928) is always more concentrated than total traffic (1932-2009), which locates at every port. Another likely reason is the central government policy limiting port traffic concentration to support regional balance internally and maintain control of port operations externally. The de-concentration observed in 2008 and 2009 is mainly explained by the impacts of the global financial crisis that slowed down the activity of the largest ports. Contrastingly, the share of the largest port has decreased continuously over time, from $62.6 \%$ in 1868 to $9.2 \%$ in 2009 . Such trend seems not influenced by changes in data units (international vs. total traffics) and wider political dynamics compared with other concentration indicators. Among explanation factors is the renew interest for inland river shipping such as along the Yangtze River Valley where new ports have constantly grown since the 1970s whereas supporting Shanghai's gateway function (Wang and Ducruet, 2012). This means that despite 
wider economic and political changes, the Chinese port system exhibits structural changes.

\section{[Insert Figure 4 about here]}

The changing rank-size distribution of Chinese ports since 1868 reveals fundamental changes in hierarchical configurations over time (Figure 5). Three main traffic regimes can be identified based on the level of traffic hierarchy: high hierarchy (1868-1932), medium hierarchy (1936-1978) and low hierarchy (1986-2009). Beyond changes in unit values, such trends underlie a progressive stabilization of the port system. Increasing hierarchical order until the late 19th century is followed by a decreasing trend until 1949, when the political change drastically alters former evolutions. The port hierarchy then remains rather de-concentrated until nowadays compared with the pre-socialist period, also because of the increasing number of ports. This indicates that the Chinese port system underwent saturation before the transition phase towards the capitalist era. Port traffic dynamics thus replicate to some extent wider economic and political changes at country level. It reflects to some extent the successive impacts of exogenous influence (i.e. foreign trade at treaty ports) and endogenous influence (i.e. socialist regime).

\section{[Insert Figure 5 about here]}

Traffic dynamics can also be analyzed among three main groups of ports (i.e. North, Yangtze, and South) defined by REISCHAUER (1940) as China's core gateways (Figure 6). Despite common trends and its lowest traffic at the beginning of the period, the northern region has grown more rapidly than other regions since the 1890s and even surpassed the southern region from the early 1900s. Traffic loss after 1949 has been less severe in the North than in other regions for three main reasons. First, proximity to the core political region (Beijing) has secured and fostered port traffics and port-related investments compared with more remote regions. Notably during the first and second five-year plans, Northeast China becomes a prime concentration of heavy industries in China. Second, northern ports are traditionally more specialized in handling bulk products such as coal and minerals, thereby making their activity more resilient to foreign trade closure than ports specialized in manufactured products. Third, northern ports benefitted from the colonization of Northeastern China by Russia and Japan, the latter having developed many industrial bases and transport infrastructures in this region. In comparison, southern ports have more suffered from the end of foreign trade due to their higher dependence upon international activities and their remoteness from the core political region, while their specialization in manufactured goods makes their traffic less weighty. The priority given to defence concerns during the 1949-1978 period resulted in lesser industrial investments and international trade at southern regions due to their proximity with Taiwan, Vietnam, Hong Kong and Macau. Despite the central role and spectacular growth of the Pearl River Delta (e.g. Shenzhen and Guangzhou) since the 1978 reforms, southern ports have remained at the third rank up to nowadays.

\section{[Insert Figure 6 about here]}

\section{Discussion and conclusion}

This research has confronted the Chinese case to existing models of port system evolution based on a study of port hierarchies since the First Unified Empire (221 BC). Across the whole period, certain long-term dynamics could have been highlighted, such as the gradual shift of largest seaports from southern to northern regions, and the shift of largest river ports from northern to southern regions. Southern and northern ports exhibit distinct development factors with a respective dominance of economical (south) and political (north) factors. The domination of river ports in a first phase is followed by a balance between river ports 
and seaports and a dominance of seaports, although the current period witnesses a rapid development of river transport in China. The wider trend of coastal concentration does not contradict the stability of the overall pattern based on three main regions: the Pearl River in south China (i.e. Guangzhou and Shenzhen), the Yangtze and Qiantang rivers in East China (i.e. Yangzhou, Ningbo, and Shanghai), and the Bohai Rim in north China (e.g. Tianjin, Dalian, and Qingdao). Main results also underlined the role of the spatial mismatch between the core political center and the core economic center in fostering north-south river shipping in the early phase. While the political center has remained in the north, there has been a regional shift of the core economic region southward through continuous transport network improvement supporting domestic trade both north-south (Grand Canal) and east-west (Yangtze). Coastal shipping between north and south becomes vital in the emergence of what has become an integrated port system. Externally, the closure of foreign trade in 1949 happened to have a rather short-term impact on traffic evolution compared with the more profound influence of foreign intervention since the late 19th century in terms of coastal concentration. In this respect, this research supports the idea of a continuous shift towards seaport activities despite several closures at different periods (Ming Dynasty and 1949-1978). Periods of openness remain largely dominant, thereby allowing the development of gateway functions and long-distance connections.

Overall, the current pattern and evolution of the Chinese port system are not disconnected from long-term historical legacies. This research thus helps rethinking nowadays dynamics as part of a wider evolution where recent trends prolong rather than contradict former ones. Main results thus point at the need to revisit existing port system evolutionary models by a combined analysis of complementary (and sometimes contradicting) trends where concentration and de-concentration dynamics occur simultaneously. Further research shall complement this approach by analyzing the changing situation of Chinese ports in the global maritime network based on worldwide inter-port vessel movement data (see DUCRUET, 2012). Another research direction is to test the co-evolution of urban and port activities since the mid-19th century based on more complete time series data so as to better explain traffic distributions in relation with hinterlands and inland connectivity.

\section{Acknowledgements}

This research was supported by the Natural Science Foundation of China (Project No. 41171108).

\section{References}

AIRRIESS C. A. (1989) The spatial spread of container transport in a developing regional economy: Sumatra, Indonesia, Transportation Research Part A 23, 453-61.

AIRRIESS C. A. (2001) The regionalization of Hutchison Port Holdings in Mainland China, Journal of Transport Geography 9, 267-78.

BRETAGNOLLE A., PUMAIN D. and VACCHIANI-MARCUZZO C. (2009) The organization of urban systems, in LANE D., VAN DER LEEUW S., PUMAIN D. and WEST G. (Eds) Complexity Perspectives in Innovation and Social Change, pp. 197-220. Springer, Methodos Series 7.

BRUNT B. (2000) Ireland's seaport system, Tijdschrift voor Economische en Sociale Geografie 91, 159-75. BUTLAND G. J. (1966) Latin America: A Regional Geography. Longman, London.

COMTOIS C. (1990) Transport and territorial development in China 1949-1985, Modern Asian Studies 24, 777-818.

COMTOIS C. and DONG J. (2007) Port competition in the Yangtze River delta, Asia Pacific Viewpoint 48, 299-311.

CULliNANE K. P. B., WANG T. F. and CULLINANE S. (2004) Container terminal development in Mainland China and its impact on the competitiveness of the port of Hong Kong, Transport Reviews 24, 
33-56.

CULlinANE K. P. B., TENG Y. and WANG T. F. (2005) Port competition between Shanghai and Ningbo, Maritime Policy and Management 32, 331-46.

DENG K. G. (1997) Chinese Maritime Activities and Socioeconomic Development, c. 2100 B.C. - 1900 A.D. Greenwood Press, Westport.

DIAMOND J. and ROBINSON J. A. (2010) Natural Experiments of History. HUP, Cambridge MS.

DUCRUET C. (2012) Ports and maritime routes in the world (1890-1925), Mappemonde 106, http://mappemonde.mgm.fr/num34/lieux/lieux12201.html (in French)

DUCRUET C., NOTTEBOOM T. E. and DE LANGEN P. W. (2009a) Revisiting inter-port relationships under the New Economic Geography research framework, in NOTTEBOOM T. E., DUCRUET C. and DE LANGEN P. W. (Eds) Ports in Proximity: Competition and Coordination among Adjacent Seaports, pp. 11-27. Ashgate, Aldershot.

DUCRUET C., ROUSSIN S. and JO J. C. (2009b) Going West? Spatial polarization of the North Korean port system, Journal of Transport Geography 17, 357-68.

FAIRBANK J. K. (1983) Maritime and continental in China's history, in FAIRBANK J. K. (Ed) The Cambridge History of China, pp. 1-27. Cambridge University Press, Cambridge.

FOLKE C. (2006) Resilience: The emergence of a perspective for social-ecological systems analyses, Global Environmental Change 16, 253-67.

FRANKEL E. G. (1998) China's maritime developments, Maritime Policy and Management 25, 235-49.

GIPOULOUX F. (2009) La Méditerranée Asiatique. CNRS, Paris.

HAYUTH Y. (1988) Rationalization and concentration of the U.S. container port system, The Professional Geographer 40, 279-88.

HILLING D. (1977) The evolution of a port system: The case of Ghana, Geography 62, 97-105.

HITCH M. A. (1935) The port of Tientsin and its problems, The Geographical Review 25, 367-81.

HOYLE B.S. (1999) Port concentration, inter-port competition and revitalization: the case of Mombasa, Kenya, Maritime Policy and Management 26, 161-74.

HOYLE B. S. and CHARLIER J. (1995) Inter-port competition in developing countries: An East African case study, Journal of Transport Geography 3, 87-103.

KENYON J. (1970) Elements in inter-port competition in the United States, Economic Geography 46, 1-24. KUBY M. and REID N. (1992) Technological change and the concentration of the U.S. general cargo port system: 1970-88, Economic Geography 68, 272-89.

LEE S. W., SONG D. W. and DUCRUET C. (2008) A tale of Asia's world ports: The spatial evolution in global hub port cities, Geoforum 39, 372-85.

LIN J. Y. (1995) The Needham puzzle: Why the Industrial Revolution did not originate in China, Economic Development and Cultural Change 43, 269-92.

LO C. P. (1989) Recent spatial restructuring in Zhujiang Delta, South China: A study of socialist regional development strategy, Annals of the Association of American Geographers 79, 293-308.

MURPHEY R. (1974) The Treaty Ports and China's modernization, in ELVIN M. and SKINNER G. W. (Eds) The Chinese City between Two Worlds, pp. 17-74. Stanford University Press, Stanford and London.

NEEDHAM J. (1954) Science and Civilisation in China. Cambridge University Press, London.

NOTTEBOOM T. E. (2006) Traffic inequality in seaport systems revisited, Journal of Transport Geography $14,95-108$.

NOTTEBOOM T. E. and RODRIGUE J. P. (2005) Port regionalization: Towards a new phase in port development, Maritime Policy and Management 32, 297-313.

OGUNDANA B. (1972) Oscillating seaport location in Nigeria, Annals of the Association of American Geographers 62, 110-21.

REISCHAUER E. O. (1940) Notes on Tang Dynasty sea routes, Harvard Journal of Asiatic Studies 5, 142-64. 
RIMMER P. J. (1967a) The changing status of New Zealand seaports, 1853-1960, Annals of the Association of American Geographers 57, 88-100.

RIMMER P. J. (1967b) The search for spatial regularities in the development of Australian seaports 1861-1961, Geografiska Annaler B 49, 42-54.

RIMMER P. J. and COMTOIS C. (2009) China's container-related dynamics, 1990-2005, Geojournal 74, 35-50.

RODRIGUE J. P., COMTOIS C. and SLACK B. (1997) Transportation and spatial cycles: Evidence from maritime systems, Journal of Transport Geography 5, 87-98.

SHIUE C. H. (2002) Transport costs and the geography of arbitrage in eighteenth-century China, American Economic Review 92, 1406-19.

SLACK B. (1985) Containerisation, inter-port competition and port selection, Maritime Policy and Management 12, 293-303.

SLACK B. (1990) Intermodal transportation in North America and the development of inland load centers, The Professional Geographer 42, 72-83.

STANLEY W. R. (1970) Transport expansion in Liberia, Geographical Review 60, 529-31.

TAAFFE E., MORRILL R. and GOULD P. R. (1963) Transport expansion in underdeveloped countries, Geographical Review 53, 503-29.

TANG Q. (2009) Inter-port transshipment between Shanghai and Hankou in foreign trade: 1864-1930, Frontiers of History in China 4, 632-52.

TODD D. (1994) Changing technology, economic growth and port development: the transformation of Tianjin, Geoforum 25, 285-303.

TVEDT T. (2010) Why England and not China and India? Water systems and the history of the Industrial Revolution, Journal of Global History 5, 29-50.

VEENSTRA A. and NOTTEBOOM T. E. (2011) The development of the Yangtze River container port system, Journal of Transport Geography 19, 772-81.

WANG C. and DUCRUET C. (2012) New port development and global city-making: Emergence of the Shanghai-Yangshan multilayered gateway hub, Journal of Transport Geography 25, 58-69.

WANG J., JIN F., MO H. and WANG F. (2009) Spatiotemporal evolution of China's railway network in the $20^{\text {th }}$ century: An accessibility approach, Transportation Research Part A 43, 765-78.

WANG J. J. and CHEN M. (2010) From a hub port city to a global supply chain management center: A case study of Hong Kong, Journal of Transport Geography 18, 104-15.

WANG J. J. and NG A. K. Y. (2011) The geographical connectedness of Chinese seaports with foreland markets: A new trend? Tijdschrift voor Economische en Sociale Geografie 102, 188-204.

WANG J. J., NG A. K. Y. and OLIVIER D. (2004) Port governance in China: A review of policies in an era of internationalizing port management practices, Transport Policy 11, 237-50.

WANG J. J. and SLACK B. (2000) The evolution of a regional container port system: The Pearl River Delta, Journal of Transport Geography 8, 263-75.

WANG J. J. and SLACK B. (2004) Regional governance of port development in China: A case study of Shanghai International Shipping Center, Maritime Policy and Management 31, 357-73.

WEBER J. (2004) Diverging narratives: Evaluating the uses of the ideal-typical sequence of transport network development, Journal of Geography 103, 211-17.

WEI Q. (1987) The development of water transport in China, Transport Reviews 7, 1-15.

WIENS H. J. (1955) Riverine and coastal junks in China's commerce, Economic Geography 31, 248-64. 


\section{APPENDIX 1: Chinese sources on port and transport activities in China}

BAI S. (1927) History of China Transportation System. Commercial Press, Beijing.

CAO Y. (1999a) Evolution model of container port system, Geography Science 19, 485-90.

CAO Y. (1999b) Spatial structure of ports system in Yangtze River, Acta Geographica Sinica 54, 233-40.

CHEN H. (1996) Developing course and formation mechanism of seaports regional cluster, Acta Geographica Sinica 51, 501-7.

CHEN Y. (1989) History of Nantong port, Beijing: China Communications Press.

FANG Z. and LI E. (2003) The Developing History of China Water Transportation. Xinhua Press, Beijing.

CHENG H. (1985) History of Guangzhou port, Beijing: Ocean Press.

DENG J. (1995) History of Yingkou port, Beijing: China Communications Press.

DENG S. (1993) History of Xiamen port, Beijing: China Communications Press.

DING S. (1988) History of Yantai port, Beijing: China Communications Press.

DONG F. (1994) Shipping history in Jiangsu province, Beijing: China Communications Press.

EDITORIAL BOARD (1993) Shipping history in Shandong province, Beijing: China Communications Press.

FANG Z. and LI E. (2003) Shipping history in China, Beijing: Xinhua Publishing.

FU C. (2005) Canal history in China, Taiyuan: Shanxi people's publishing house.

GU C. (1992) Urban system in China: history, status and future, Beijing: The Commercial Press.

GU Y. and LI Z. (1988) History of Beihai port, Beijing: China Communications Press.

GUI Y. (1992) History of Tianjin port, Beijing: China Communications Press.

HAN Z. and AN X. (2002) Distribution of international container transportation networks, Acta Geographica Sinica 57, 479-88 (in Chinese).

HU H. (1990) Proceedings of Hu Huanyong's population geograpy paper, Beijing: China Financial and Economic Publishing House.

HUANG S. (1951) Development of China port cities, Acta Geographica Sinica 18, 20-40 (in Chinese).

HUANG J. (1985) History of Qinhuangdao port, Beijing: China Communications Press.

HUANG J. and CHEN X. (2000) Lateral development and change between the transport and history, Beijing: People's Publishing House.

JIN C. (1995) History of Haimen port, Beijing: China Communications Press.

LAI D. (1998) Shipping history of Pearl River, Beijing: China Communications Press.

LIN K. (1994) Shipping history in Fujian province, Beijing: China Communications Press.

LONG S. (1990) History of Chongqing port, Wuhan: Wuhan Publishing House.

LU H. (1989) History of Nanjing port, Beijing: China Communications Press.

LIANG F. (1982) Statistics of population, land and land tax in each dynasty in China, Beijing: Zhonghua Book Company.

LUO C. (1991) Shipping history of Yangtze River, Beijing: China Communications Press.

MA Y. (1991) Shipping history in Guangxi province, Beijing: China Communications Press.

MA Z. (1990) History of Mingsheng Company, Beijing: China Communications Press.

MAO B. (1980) History of Shanghai port, Beijing: China Communications Press.

QIAN Y. (1995) River shipping history in Shanghai, Beijing: China Communications Press.

SHEN X. (1991) River shipping history in Jiangxi province, Beijing: China Communications Press.

SHENG S. (1931) Transportation Geography. Commercial Press, Beijing.

SHI J. (1989) History of Huangpu port, Beijing: China Communications Press.

SUN S. (1991) History of Jiujiang port, Beijing: China Communications Press.

TONG L. (1993) Shipping history in Zhejiang province, Beijing: China Communications Press.

WANG S. (1988) River shipping history in Sichuan province, Chengdu: Sichuan's People Press.

WANG S. (1988) Shipping history in Hebei province, Beijing: China Communications Press.

WANG Y. (2006) Social change of region along the Grand Canal in Ming and Qing Dynasty, Beijing: People's 
Publishing House.

WU J. (1988) History of Yangzhou's old port, Beijing: China Communications Press.

WU Z. (1989) History of Hangzhou's old port, Beijing: China Communications Press.

XU C. (1995) Shipping history in Hubei province, Beijing: China Communications Press.

XU D. (1987) History of Lianyungang port, Beijing: China Communications Press.

YE X. (1989) Shipping history in Guangdong province, Beijing: China Communications Press.

ZHANG G. (1991) History of Xiangfan port, Beijing: China Communications Press.

ZHANG H. (1988) History of China Merchants Group, Beijing: China Communications Press.

ZHANG L. (1989) History of Zhenjiang port, Beijing: China Communications Press.

ZHANG S. (1989) Shipping history in Henan province, Beijing: China Communications Press.

ZHANG S. (1997) The population geography in China, Beijing: The Commercial Press.

ZHANG Z. (1986) Marine Transportation of China Antiquity. Commercial Press, Beijing.

ZHENG S. (1989) History of Ningbo port, Beijing: China Communications Press.

ZHENG S. (1994) History of Wuhan port, Beijing: China Communications Press.

ZHENG Y., LIN Y. and ZHANG X. (1996) History of Fuzhou port, Beijing: China Communications Press.

ZHOU H. (1990) History of Wenzhou port, Beijing: China Communications Press.

ZHU Q. (1962) History of China Canal. Chinese Press, Beijing.

ZOU B., HE F. and HE W. (1990) The development and improvement of the Grand Canal, Beijing: Water Conservancy and Electric Power Press. 
Figure 1: Port and urban hierarchies in the 221 B.C. - 1840 period
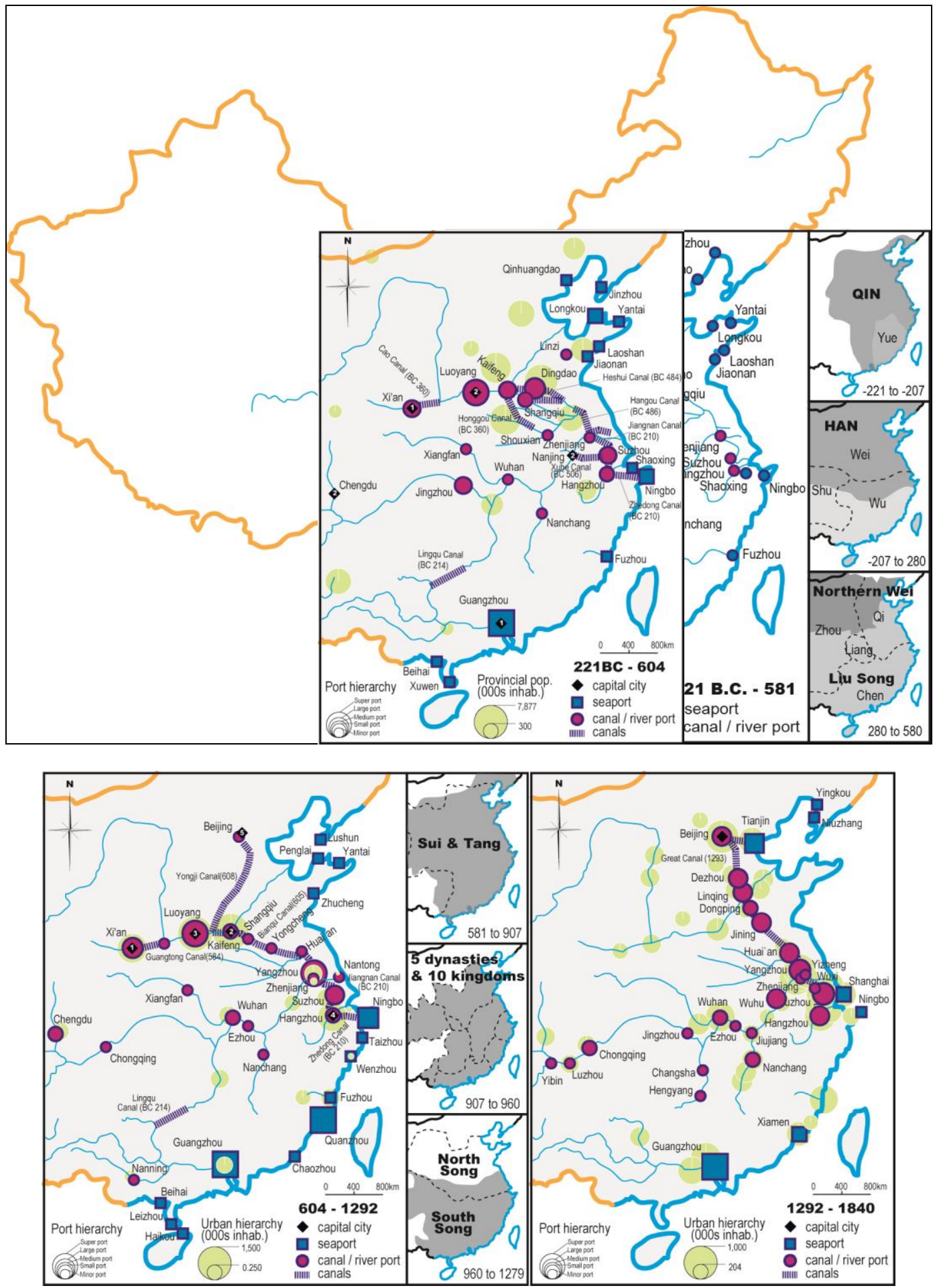

Source: own elaboration based on historical records 
Figure 2: Closure and openness measures on China's maritime trade, 1292-1757

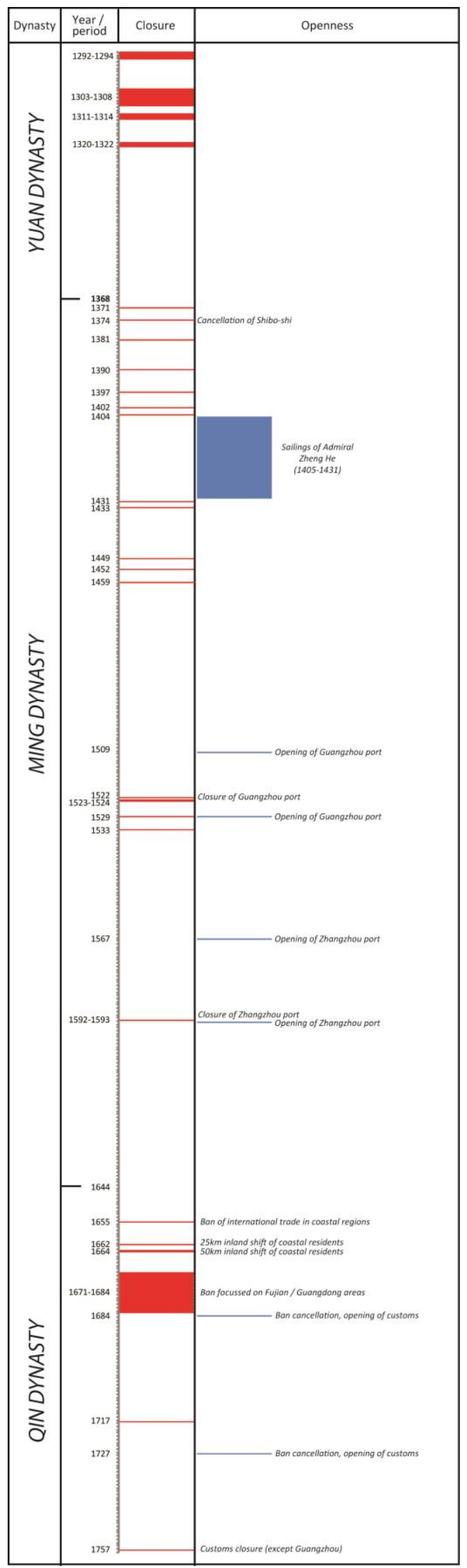

Source: own elaboration based on historical records 
Figure 3: Port traffic evolution and distribution, 1868-1928
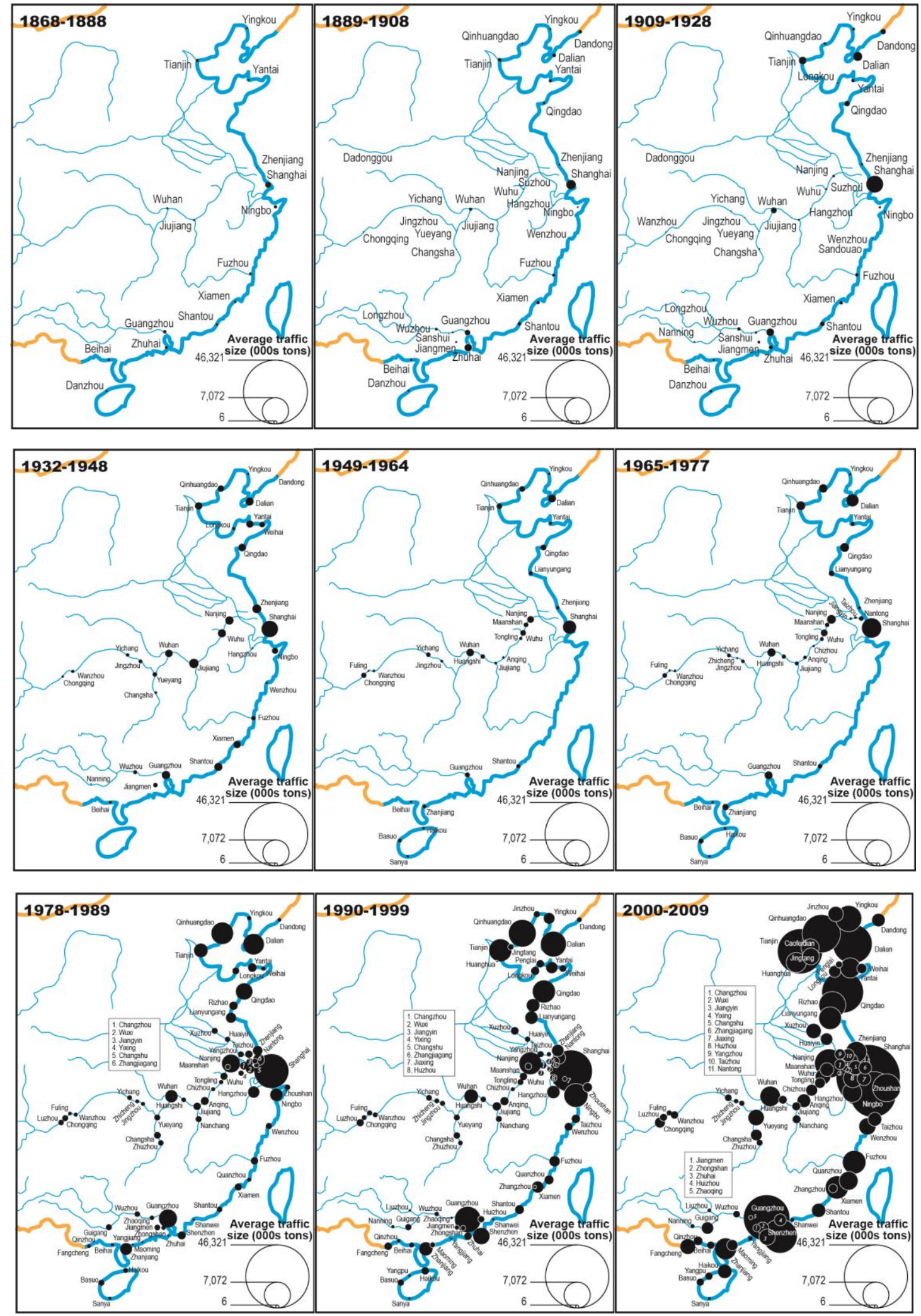

Source: own elaboration based on official statistics 
Figure 4: Port traffic concentration, 1868-2009

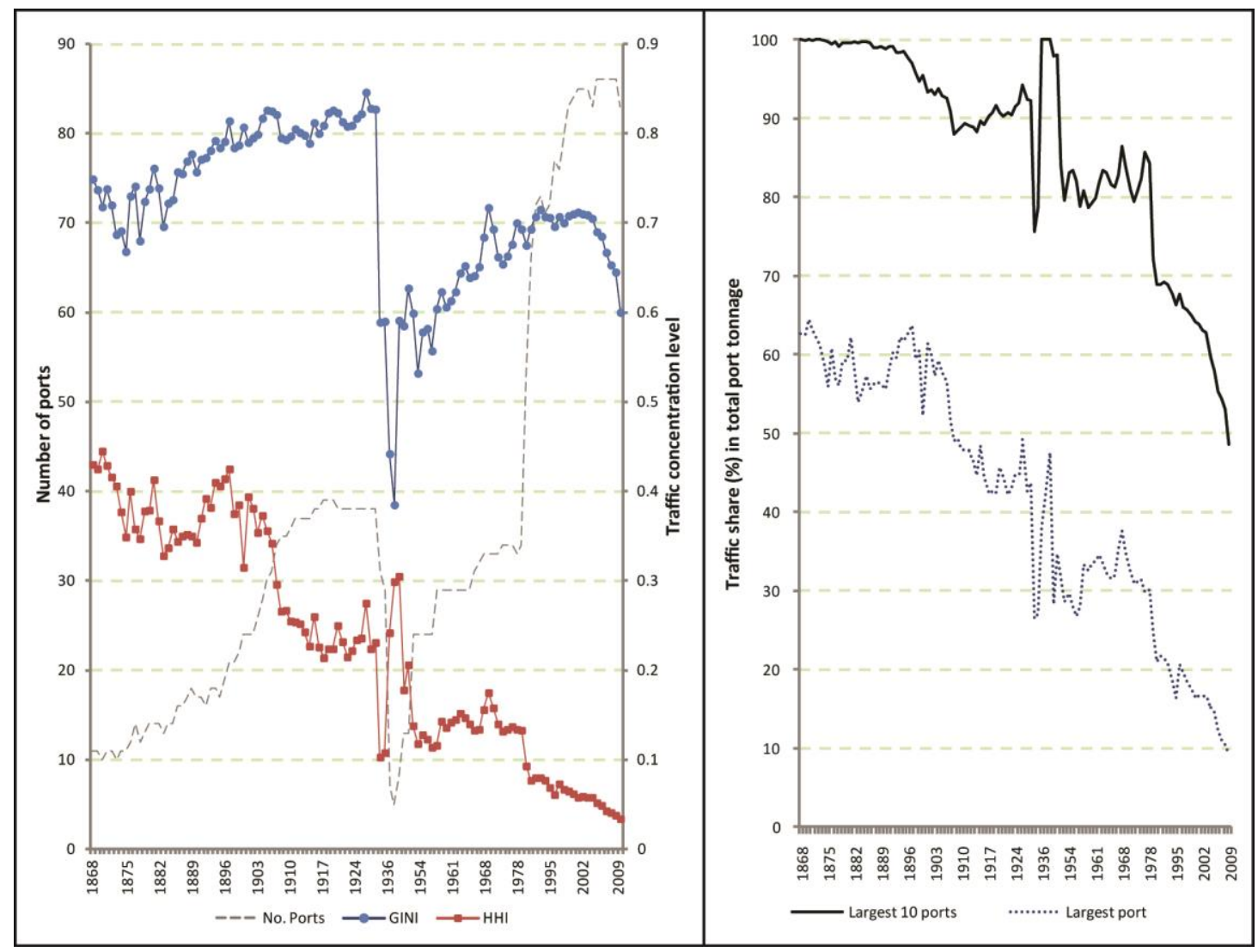

Source: own elaboration based on official statistics

Figure 5: Rank-size distribution of port traffics, 1868-2009

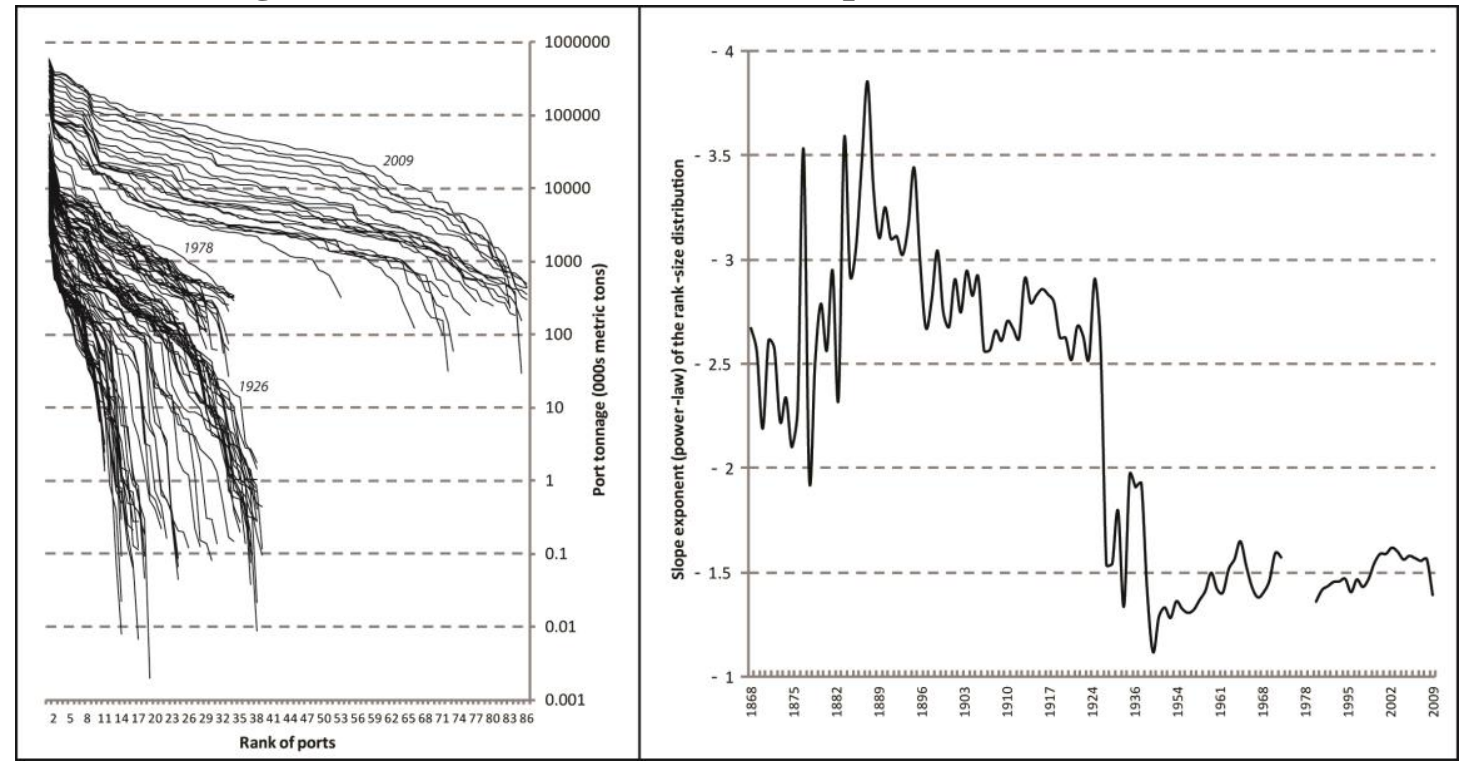

Source: own elaboration based on official statistics 
Figure 6: Traffic evolution by range, 1868-2009 and 1979-2010

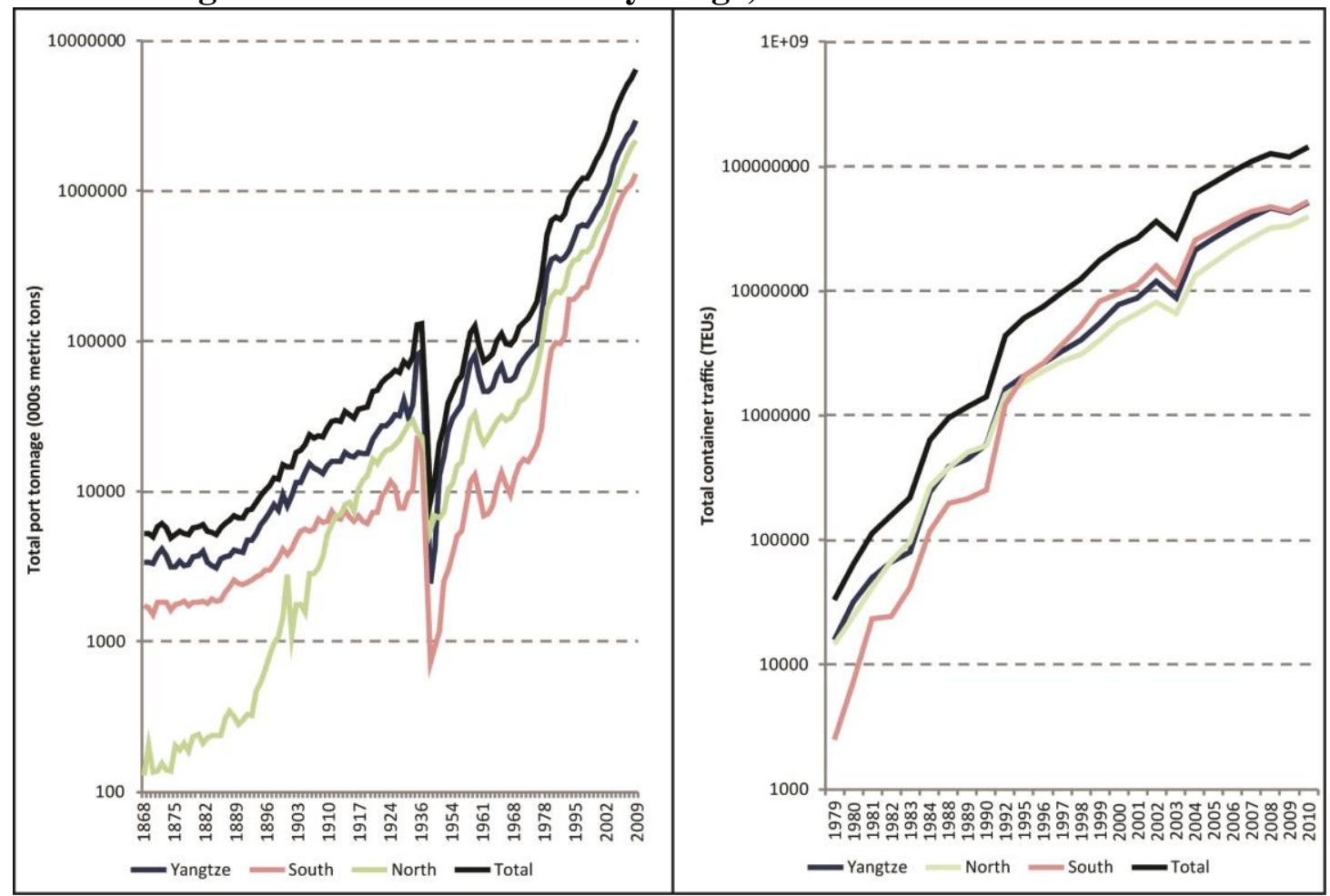

Source: own elaboration based on official statistics

${ }^{1}$ Chinese unit of weight used on the Hong Kong market and some other centers such as Taiwan. 1 tael $=1.20337$ troy ounces ( 37.4290 grams). The nominal fineness of the Hong Kong taelbar is 990 but in Taiwan, 5 and 10 tael bars may be 999.9 fine. The bars traded are normally 5 and 10 taels, although a 1 tael bar, shaped like a slipper bath, is also sold to investors. The basic contract on the Hong Kong Gold and Silver Exchange occurs on the basis of 100 taels, each composed of twenty 5-tael bars.

${ }^{2}$ This phase includes the development of the Ling canal (Guangxi) between Yangtze and Pearl River deltas, the Hong canal (Henan) between Yellow and Huai rivers, the dredging of Ji, Hu, Huai, Si, Yellow, and Yangtze rivers, as well as the opening of main shipping routes over the Hong canal and the Yangtze river (i.e. Xi'an-Yangtze, Xi'an-Guangzhou, Guangzhou-Chengdu, and Guangzhou-Yangtze).

${ }^{3}$ The Tongji Canal connects the Yellow river (Xingyang, Henan) with the Huai river (Xuyu, Anhui) while the Yongji Canal connects the Yellow river (Wuzhi, Henan) with the Hai river (Beijing).

${ }^{4}$ Other canals complement such developments, such as the Jiangnan, Jizhou, and Huitong canals. There are records of transshipping warehouses in Linqing under Ming dynasty as well as new terminals built in Beijing (Jishuitan, Zhangjiawan).

${ }^{5}$ Shibo Shi and Shibo Si are government organizations in early times that are similar to the customs. Notably, Guangzhou was elected Shibo Shi in 714 (Tang dynasty) and upgraded to the status of Shibo Si in 917 (Song dynasty). Such status enabled Guangzhou to become the starting port for overseas shipping and voyage mileage (Tonghai Yidao). While other offices were opened during North Song dynasty (Hangzhou, Ningbo, Quanzhou, and Zhucheng) South Song dynasty re-concentrated them in the south (Fujian, Zhejiang, and Guangdong). A similar trend occurred later on with the opening of new offices northward under Yuan dynasty (Quanzhou, Qingyuan, Shanghai, Ganpu, Guangzhou, Wenzhou, and Hangzhou) followed by their closure and re-shift southward after the 1522 ban of maritime trade under Ming dynasty (Guangzhou, Ningbo, and Quanzhou), as well as another northward spread in 1683 under Qing dynasty (Guangzhou, Xiamen, Ningbo, and Shanghai) and a third ban of maritime trade in 1757 shifting all customs operations back to Guangzhou. The geography of customs offices is thus a good indicator of port and trading activities.

${ }^{6}$ During South Song dynasty, Quanzhou becomes the third largest port through its direct call function between Guangzhou and Hangzhou, while Fuzhou is designed as Shibo Si in 1474, reflecting upon its intense port activities during Sui and Five dynasties.

${ }^{7}$ Several historical records confirm the use of Quanzhou by numerous merchants as their starting base for overseas trade and for calculating sailing mileage. Its decline under late Yuan Dynasty is caused by war destructions, the shift of Shibo Si status to Fuzhou, as well as traffic shift from Quanzhou to Xiamen due to the silting of the Jin River during Ming dynasty.

${ }^{8}$ About 715,000 tons (1 shi $=71.5$ kilogrammes).

${ }^{9}$ The loss of trade independence forced the Chinese government to design Guangzhou, Fuzhou, Xiamen, Ningbo, and Shanghai as open trading ports under the Sino-British Treaty of Nanjing (1842). Other ports were also opened, such as Niuzhuang, Dengzhou, Tainan, Danshui, Chaozhou, Qingzhou, and Nanjing under the Tientsin Treaty, Tianjin under the Sino-British Treaty of Peking, as well as Wuhu, Yichang, and Chongqing under the Sino-British Yantai Treaty. The Sino-Japanese Treaty of Shimonoseki had a similar influence with the designation of Jingzhou, Shashi, Chonqing, Suzhou, and Hangzhou as open trading ports. 